\title{
Guided Worksheet Formal Definition of Limit: An Instrument Development Process
}

\author{
Rina Oktaviyanthi 1, Ria Noviana Agus 2
}

DOI: 10.35445/alishlah.v13i1. 483

Info Artikel

Keywords: Content analysis

Formal definition of limit Formal worksheet of limit Guided worksheet

Development research

\section{Abstract}

This study aims to develop a guided worksheet to fulfil the needs of students to understand the formal concept of Limit. This was carried out using a developmental study that focuses on content analysis and expert review through substantial analysis, structural design, prototype development and evaluation. The research sample was 95 first-year students, especially those in engineering and science majors who enrolled in Calculus. The data process of instrument development, the data of expert validation, and the data of limited trial were produced in this research. To assess all the research data applied the Q-Cochran and the Cronbach Alpha statistical test. The results are a guided worksheet for limit evaluation in visual form with schematic design and scaffolding or framework type. Expert testing and limited testing showed Asymp.Sig. = 0,088 $>0,05$ and $r_{\text {coefficient }}=0,382>r_{\text {critical }}=0,2017$. It indicates that the items composing this guided worksheet are valid and reliable therefore, they can be used to solve student difficulties related to the formal rules of Limit.

\begin{abstract}
Abstrak
Penelitian ini memusatkan pada bagaimana merancang dan menyusun lembar kerja terbimbing sebagai pemenuhan kebutuhan mahasiswa dalam upaya memahami konsep formal Limit. Penelitian pengembangan dengan fokus analisis konten (content analysis) dan asesmen ahli (expert review) melalui tahapan analisis dan desain, pengembangan dan evaluasi dipilih sebagai pendekatan penelitian. Sampel penelitian adalah mahasiswa tahun pertama jurusan teknik maupun sains yang mengambil mata kuliah Kalkulus dan dipilih secara random sebanyak 95 mahasiswa. Penelitian ini menghasilkan tiga data yakni (1) data proses pengembangan instrumen dalam hal ini lembar kerja terbimbing evaluasi limit dengan definisi formal, (2) data validasi ahli berupa uji keseragaman dan keterbacaan instrumen, dan (3) data uji coba terbatas pada sampel penelitian. Uji Statistika Q-Cochran menggunakan SPSS diaplikasikan untuk menguji keseragaman dan keterbacaan validator terhadap instrumen yang dinilai. Sementara validitas instrumen dari uji coba terbatas pada komunitas dihitung melalui uji Cronbach Alpha. Temuan penelitian berupa lembar kerja terbimbing evaluasi limit dalam bentuk visual dengan desain skematis dan tipe perancah atau kerangka (scaffolding). Uji ahli dan uji coba terbatas masing-masing menunjukkan nilai Asymp.Sig. $=0,088>0,05$ dan nilai $r_{\text {hitung }}=0,382>r_{\text {kritis }}=0,2017$. Nilai tersebut mengindikasikan bahwa butir soal yang menyusun lembar kerja terbimbing ini dinyatakan kredibel dan reliabel. Dengan demikian lembar kerja tersebut dapat digunakan untuk menyelesaikan kesulitan mahasiswa yang berkaitan dengan aturan formal limit.
\end{abstract}

\footnotetext{
${ }^{1}$ Universitas Serang Raya, Banten, Indonesia

Email: rinaokta@unsera.ac.id

${ }_{2}$ Universitas Serang Raya, Banten, Indonesia

Email: riaagus@unsera.ac.id
} 


\section{PENDAHULUAN}

Kalkulus menjadi landasan awal bagi mahasiswa tingkat satu di universitas sebagai pembiasaan berpikir logis dan sistematis untuk membangun pola nalar dan alur pikir kritis menuju berpikir matematika tingkat tinggi (Hagman, Johnson \& Fosdick, 2017; Dibbs, 2019). Limit adalah salah satu dari sekian banyak konsep pembentuk Kalkulus yang menjadi bab wajib dipelajari oleh mahasiswa tahun pertama khususnya di jurusan teknik dan sains. Secara keseluruhan, ide dan konsep Limit masih menjadi tantangan mahasiswa untuk dipahami dan didalami khususnya pada evaluasi limit menggunakan definisi formal. Salah satu penyebabnya adalah proses pengerjaan yang bukan prosedural aljabar biasa melainkan melibatkan abstraksi tingkat tinggi melalui epsilon dan delta. Dikatakan oleh Bakhy, Kalimbetov \& Khabibullayev (2018) kegiatan mengevaluasi nilai limit dengan menggunakan definisi formal merupakan kegiatan mengonstruksi bukti dan membuat generalisasi. Sementara Schoenfield (2018) dan Hanna (2020) menegaskan pembuktian dan menggeneralisasi termasuk dalam berpikir matematika tingkat tinggi yang masih dianggap sulit, memerlukan fokus ekstra dan menjadi tantangan besar untuk dihadapi oleh sebagian besar mahasiswa. Berdasarkan hal tersebut, menginvestigasi pemahaman konsep Limit mahasiswa yang menekankan pada definisi formal masih menjadi hal penting untuk ditinjau dan ditelusuri lebih rinci.

Sejumlah fakta lapangan hasil penelusuran pendahuluan penelitian selama dua tahun terakhir pada mahasiswa di lingkungan Universitas Serang Raya diketahui kendala mahasiswa ketika mempelajari konsep Limit terutama yang berhubungan dengan definisi formal. Kendala tersebut diantaranya yaitu kesulitan dalam mengubah konsep intuitif ke bentuk aturan formal, tidak memahami konsep proposisi dalam definisi formal Limit, lemahnya argumentasi logis dalam mengonstruksi frasa definisi formal Limit, dan tidak mengetahui kunci utama dalam mengevaluasi nilai limit menggunakan definisi formal (Oktaviyanthi, Herman \& Dahlan, 2018). Poin-poin tersebut didukung kajian Lithner (2017) dan Leikin \& Elgrably (2020) yang menyebutkan bahwa prosedur mengurai nilai limit dengan aturan formal memerlukan pengalaman dan interaksi dengan proses matematis ketat dan pengetahuan strategik pada pembuktian matematis kompleks. Sementara yang terjadi pada mahasiswa di lingkungan Universitas Serang Raya belum menunjukkan kemajuan yang siginifikan pada pengetahuan strategik dan pengalaman pembuktian formal matematis. Hal tersebut ditelusuri dalam penelitian pendahuluan melalui observasi dan hasil pekerjaan mahasiswa. Fakta masih lemahnya kemampuan mahasiswa dalam mengevaluasi limit menggunakan definisi formal berdampak pada tujuan kognitif yang ingin dibangun secara umum pada mata kuliah Kalkulus (Dibbs, 2019; Ashraf, 2020).

Richard, Venant \& Gagnon (2019) dan Alsina et al. (2021) mengungkapkan bahwa alasan yang paling mungkin ditelusuri belum tereksplorasinya kemampuan mahasiswa dalam melakukan evaluasi nilai limit menggunakan definisi formal adalah terkait penggunaan instrumen belajar yang kompatibel dan implementasi model pembelajaran yang adaptabel. Lebih jauhnya Spivak (2018) menegaskan konsep pembuktian definisi memerlukan pendekatan pembelajaran tertentu untuk menghindari miskonsepsi. Selain itu Kahl (2020) menambahkan dalam menyampaikan konsep formal setidaknya digunakan instrumen belajar yang visible dengan alur khusus untuk merinci setiap frasa yang terdapat pada definisi. Salah satu instrumen belajar yang dimungkinkan dapat mengakomodasi kebutuhan khusus dalam mempelajari suatu aturan formal atau yang berhubungan dengan alur pembuktian disebutkan oleh Oktaviyanthi, Herman \& Dahlan (2018) dan Flórez \& Mukherjee (2020) yakni berupa lembar kerja terpadu yang berfungsi membimbing alur kerja mahasiswa. Lembar kerja yang memiliki karakteristik membedah suatu aturan formal tertentu sehingga lebih mudah dipahami dan diikuti oleh mahasiswa, termasuk di dalamnya aturan formal limit, masih menjadi salah satu topik riset yang diutamakan setidaknya pada kurun waktu lima tahun terakhir. 
Beberapa penelitian yang memfokuskan pada pengembangan dan penggunaan lembar kerja pada konsep-konsep matematika sudah banyak dilakukan kurang lebih dalam periode lima tahun kebelakang. Barniol \& Zavala (2016) dan Luthfiana, Ambarita \&Suwarjo (2018) masing-maisng menyusun lembar kerja untuk membantu peserta didik mengembangkan interpretasi pada $d o t$ product dan optimalisasi berpikir kreatif dengan melibatkan kecerdasan majemuk. Sementara Ingram et al. (2019) mengembangkan challenging tasks sebagai upaya menelusuri pendekatan pembelajaran inovatif bagi calon guru. Lalu Ayalon \& Wilkie (2020) menguji lembar kerja untuk materi fungsi kuadrat dalam kerangka literasi matematika menggunakan approximations of practice. Secara umum hasil penelitian pengembangan lembar kerja kelima penelitian tersebut memenuhi standar validitas instrumen sehingga dapat digunakan untuk menjaring data penelitian. Berbeda dengan penelitian Nasrullah, Marlina \& Dwiyanti (2018) yang mengembangkan alat ukur hasil belajar Matematika Ekonomi menggunakan lembar kerja dikolaborasikan dengan pembelajaran daring melalui Edmodo. Kemudian penelitian yang menitikberatkan pada konsep Limit dilakukan oleh penulis sendiri pada tahun 2018 sebagai penelusuruan awal mengenai kesulitan mahasiswa dalam memahami konsep Limit menggunakan definisi formal (Oktaviyanthi, Herman \& Dahlan, 2018). Pada tahun yang sama dilakukan penelitian pengembangan lembar kerja terbimbing berbasis Cognitive Apprenticeship (Oktaviyanthi \& Dahlan, 2018). Hasil penelitian kolaborasi lembar kerja dengan pendekatan atau model pembelajaran tertentu menyatakan bahwa peran lembar kerja dapat memberikan pengaruh pada hasil capaian peserta didik dalam pembelajaran. Selanjutnya, hasil penelitian sebelumnya menyatakan pula bahwa penggunaan lembar kerja sebagai instrumen bantu dalam menanamkan konsep tertentu termasuk matematika cukup berhasil dan berdampak positif. Namun dari hasil penelitian terkait lembar kerja tersebut belum ada lembar kerja yang fokus pada visibilitas ide sentral mengevaluasi limit menggunakan definisi formal. Padahal dalam paparan sebelumnya disampaikan bahwa masalah utama dalam penelitian ini adalah mengonstruksi frasa definisi formal Limit dan pengetahuan strategik mahasiswa.

Berdasarkan pemaparan masalah yang dihadapi mahasiswa terkait prosedur mengevaluasi nilai limit menggunakan definisi formal dan dampak yang cukup baik pemanfaatan lembar kerja bagi pemahaman konsep suatu materi, maka penelitian ini bertujuan untuk menyusun dan merancang lembar kerja terbimbing sebagai pemenuhan kebutuhan mahasiswa dalam upaya memahami konsep formal Limit. Serangkaian prosedur pengembangan instrumen dilakukan untuk memperoleh lembar kerja terbimbing yang valid dan reliabel serta menjadi solusi dari masalah yang dihadapi mahasiswa.

\section{METODE}

Sesuai dengan tujuan penelitian yaitu menyusun dan merancang instrumen lembar kerja terbimbing dalam mengevaluasi nilai limit menggunakan definisi formal, maka penelitian pengembangan ditetapkan sebagai pendekatan penelitian yang digunakan. Metode pengembangan instrumen merujuk pada salah satu pola pengembangan instrumen penelitian yaitu analisis konten (content analysis) dan review ahli (expert review) (Richey, Klein \& Tracey, 2010). Desain penelitian pengembangan untuk mendapatkan instrumen yang valid difokuskan pada tiga tahapan yaitu analisis dan desain, pengembangan dan evaluasi. Diagram alur tahapan pengembangan lembar kerja terbimbing disajikan pada Gambar 1. Berikut uraian kegiatan per tahapan penelitian.

Tahap analisis dan desain ditujukan untuk mengidentifikasi masalah dan menentukan desain solusi sesuai kebutuhan. Adapun kegiatan yang dikerjakan pada tahap pertama ini diantaranya yaitu merinci masalah utama dan menetapkan masalah turunan yang mungkin muncul melalui penelusuran kegiatan belajar sebelumnya. Aspek yang dijadikan bahan identifikasi dari kegiatan belajar sebelumnya adalah bahan ajar yang digunakan pengajar, pendekatan belajar yang diimplementasikan, hasil dan respon mahasiswa. Selanjutnya, pada bagian desain dilakukan penegasan tujuan pembelajaran dan penyusunan strategi pembelajaran berdasarkan hasil 
investigasi tahap analisis. Beberapa kegiatan dalam ruang lingkup tahap desain yaitu merancang struktur instrumen yang bersesuaian dengan masalah, mengatur konten instrumen sehingga masalah yang dihadapi dapat dengan tepat diatasi dan membuat sistematika strategi instrumen yang mengakomodasi tujuan pembelajaran.

Tahap pengembangan dimaksudkan sebagai langkah praktis di tahap desain yang menghasilkan prototipe instrumen. Kegiatan pada tahap ini yaitu perwujudan ide dalam bentuk teori menjadi model instrumen sesuai standar penelitian yang didefinisikan di awal. Kemudian tahap terakhir yaitu tahap evaluasi yang bertujuan untuk menilai kelayakan, menginterpretasi hasil validasi dan melakukan improvisasi prototipe instrumen sebelum digunakan secara umum. Kegiatan yang termasuk dalam tahap evaluasi adalah analisis konten dan review ahli melalui uji keseragaman substansi dan uji keterbacaan struktur lembar kerja dan validasi instrumen melalui uji coba skala kecil pada sejumlah subjek penelitian.

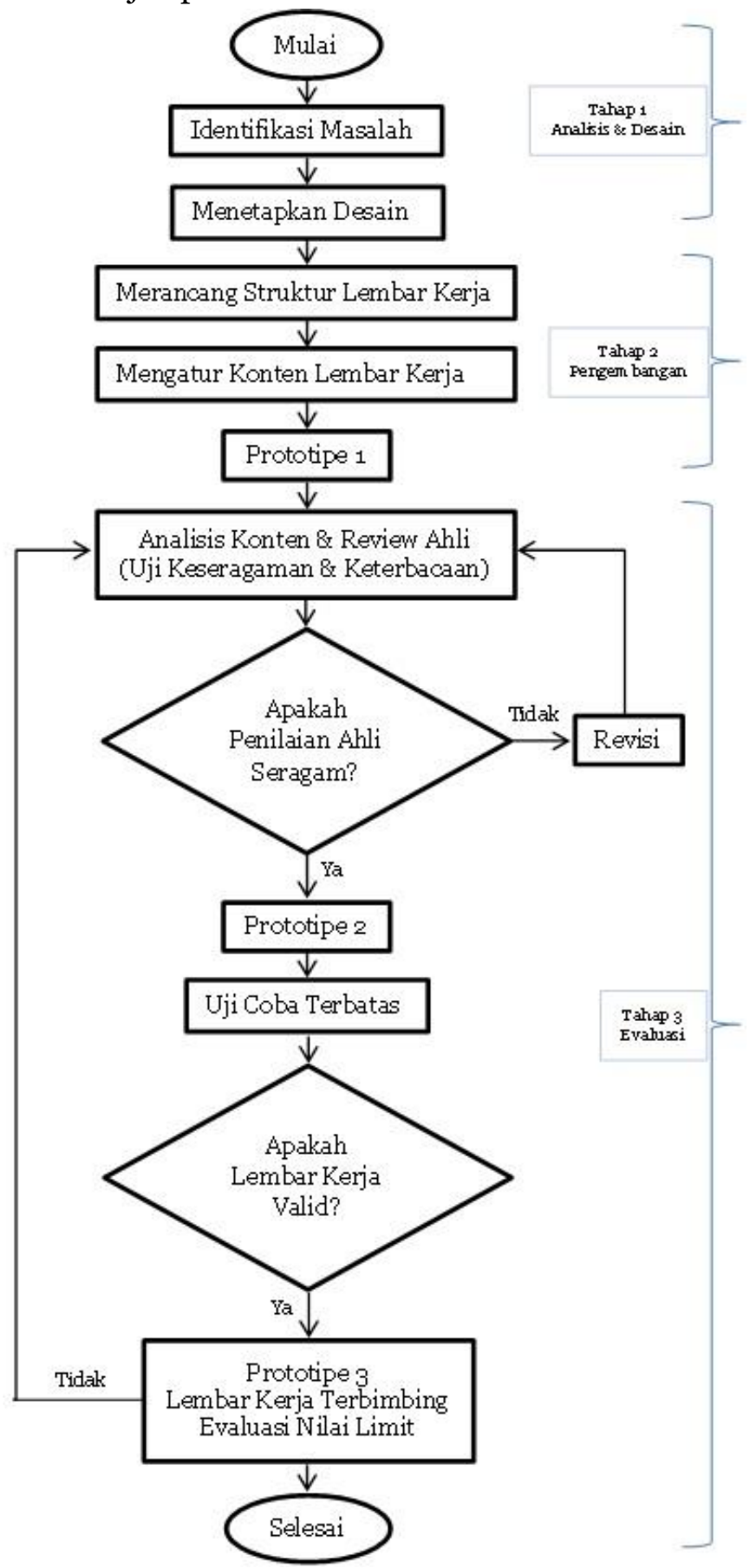

Gambar 1. Diagram alur tahapan pengembangan lembar kerja terbimbing 
Pengambilan data uji ahli dilakukan melalui lembar validasi ahli berupa angket dengan 2 skala penilaian ( 1 = Setuju, o = Tidak Setuju). Adapun indikator penilaian masing-masing ahli mengacu pada aspek penilaian yang disampaikan Akbar (2016) dan Krosnick (2018) dengan pengembangan sesuai tujuan penelitian. Indikator yang dimaksud disajikan pada Tabel 1. di bawah ini.

Tabel 1. Kriteria Penilaian Lembar Kerja Terbimbing

\begin{tabular}{|c|c|c|}
\hline Aspek & Indikator & Butir Angket \\
\hline \multirow{4}{*}{$\begin{array}{l}\text { Substansi materi } \\
\text { matematika }\end{array}$} & $\begin{array}{l}\text { Kesesuaian isi lembar kerja terbimbing dengan konsep } \\
\text { proposisi dalam definisi formal limit }\end{array}$ & 1 dan 2 \\
\hline & $\begin{array}{l}\text { Kesesuaian isi lembar kerja terbimbing dengan alur } \\
\text { identifikasi nilai delta }\end{array}$ & 3 dan 4 \\
\hline & $\begin{array}{l}\text { Kesesuaian isi lembar kerja terbimbing dengan proses } \\
\text { perubahan bentuk intuitif konsep limit ke bentuk aturan } \\
\text { formal }\end{array}$ & 5 dan 6 \\
\hline & $\begin{array}{l}\text { Kesesuaian isi lembar kerja terbimbing dengan tahapan } \\
\text { mengonstruksi bukti secara formal }\end{array}$ & 7 dan 8 \\
\hline \multirow{4}{*}{$\begin{array}{l}\text { Struktur lembar } \\
\text { kerja terbimbing }\end{array}$} & $\begin{array}{l}\text { Kesesuaian konsep proposisi dalam definisi formal limit } \\
\text { dengan desain diagram alir pola implikasi }\end{array}$ & 9 dan 10 \\
\hline & $\begin{array}{l}\text { Kesesuaian alur identifikasi nilai delta dengan tampilan } \\
\text { melengkapi grafik dan menentukan letak kisaran nilai epsilon } \\
\text { dan delta }\end{array}$ & 11 dan 12 \\
\hline & $\begin{array}{l}\text { Kesesuaian proses perubahan konsep limit dari intuitif ke } \\
\text { bentuk formal dengan struktur alur kerja pembuktian }\end{array}$ & 13 dan 14 \\
\hline & $\begin{array}{l}\text { Kesesuaian konstruksi bukti formal dengan desain isian tabel } \\
\text { sistematika pembuktian limit }\end{array}$ & 15 dan 16 \\
\hline \multirow{4}{*}{$\begin{array}{l}\text { Penggunaan kalimat } \\
\text { dan tata bahasa }\end{array}$} & $\begin{array}{l}\text { Kesesuaian kalimat dengan materi dan struktur lembar kerja } \\
\text { terbimbing }\end{array}$ & 17 dan 18 \\
\hline & $\begin{array}{l}\text { Kesesuaian tata bahasa dengan tujuan masing-masing soal } \\
\text { dalam lembar kerja terbimbing }\end{array}$ & 19 dan 20 \\
\hline & $\begin{array}{l}\text { Kesesuaian kalimat dan tata bahasa dengan keruntutan alur } \\
\text { berpikir dalam lembar kerja terbimbing }\end{array}$ & 21 dan 22 \\
\hline & $\begin{array}{l}\text { Kesesuaian penggunaan istilah, simbol dan lambang dalam } \\
\text { lembar kerja terbimbing }\end{array}$ & 23 dan 24 \\
\hline
\end{tabular}

Selanjutnya uji Q-Cochran digunakan untuk mengolah data uji ahli dengan hipotesis pengujian yaitu:

$\mathrm{H}_{\mathrm{o}} \quad$ : Pertimbangan validasi dari kelima validator untuk lembar kerja terbimbing seragam

$\mathrm{H}_{1} \quad$ : Pertimbangan validasi dari kelima validator untuk lembar kerja terbimbing tidak seragam Rumus Statistik uji Q-Cochran yaitu (Katranc1, 2018):

\section{Keterangan:}

$$
Q=\frac{(k-1)\left[k \sum_{j=1}^{k} G_{j}{ }^{2}-\left(\sum_{j=1}^{k} G_{j}\right)^{2}\right]}{k \sum_{i=1}^{N} G_{j}-\sum_{i=1}^{N} L_{i}{ }^{2}}
$$

$\mathrm{G}_{\mathrm{j}} \quad$ : jumlah sukses di dalam kelompok ke-j

$\mathrm{L}_{\mathrm{i}} \quad$ : jumlah sukses di dalam kelompok ke-i

$\mathrm{k} \quad$ : banyaknya kolom atau perlakuan

Dengan taraf signifikansi $5 \%$, keputusan tolak $\mathrm{H}_{\mathrm{o}}$ adalah ketika $Q \geq X^{2}{ }_{(\alpha ; k-1)}$ atau $p-$ value $\leq$ $\alpha$ (Mohajan, 2017). Pada penelitian ini, uji Q-Cochran menggunakan bantuan SPSS IBM 25 memiliki kriteria penerimaan $\mathrm{H}_{\mathrm{o}}$ jika nilai probabilitas (Sig.) $>\alpha=0,05$. Hal ini berarti kelima validator menunjukkan pertimbangan validasi yang tidak berbeda atau seragam untuk lembar kerja terbimbing yang dirancang. 
Sementara pengambilan data uji coba terbatas dilakukan melalui pengisian lembar kerja terbimbing yang telah valid dan direvisi sesuai saran perbaikan validator. Secara berurutan bobot soal dalam lembar kerja terbimbing mulai soal nomor 1 hingga soal nomor 4 yaitu 10, 30, 20 dan 40 sehingga skor total bernilai 100. Skor masing-masing mahasiswa kemudian dihitung melalui uji Cronbach Alpha menggunakan bantuan SPSS IBM 25. Kriteria butir soal dalam lembar kerja terbimbing dikatakan valid dan reliabel jika nilai $r_{\text {hitung }}>r_{\text {kritis }}$ (Mohajan, 2017; Katranc1, 2018).

Populasi penelitian yaitu mahasiswa di lingkungan Universitas Serang Raya dengan sampel mahasiswa tahun pertama jurusan teknik maupun sains yang mengambil mata kuliah Kalkulus dan dipilih secara random sebanyak 95 mahasiswa. Untuk uji ahli yang bertugas melakukan validasi isi dan muka instrumen adalah 5 orang yakni ahli di bidang matematika sebanyak 2 orang untuk menilai kesesuaian isi materi matematika pada lembar kerja terbimbing dengan tujuan penelitian, ahli di bidang pendidikan matematika sebanyak 2 orang untuk menilai kesesuaian struktur instrumen dengan tujuan penelitian, dan ahli di bidang bahasa sebanyak 1 orang untuk menilai penggunaan kalimat dan tata bahasa dalam lembar kerja.

Penelitian ini menghasilkan tiga data yakni (1) data proses pengembangan instrumen dalam hal ini lembar kerja terbimbing evaluasi limit dengan definisi formal, (2) data validasi ahli berupa uji keseragaman dan keterbacaan instrumen, dan (3) data uji coba terbatas pada sampel penelitian. Uji Statistika Q-Cochran menggunakan SPSS diaplikasikan untuk menguji keseragaman dan keterbacaan validator terhadap instrumen yang dinilai. Sementara validitas instrumen dari uji coba terbatas pada komunitas dihitung melalui uji Cronbach Alpha.

\section{HASIL PENELITIAN DAN PEMBAHASAN}

\section{Analisis dan Desain}

Pembelajaran materi limit khususnya pada konsep definisi formal limit dalam kurun waktu tahun 2018-2020 menerapkan metode ceramah dengan bantuan slide power point. Alat evaluasi pemahaman konsep definisi formal limit yang digunakan berupa soal latihan yang terdapat dalam buku sumber. Refleksi pengajar yang bersumber hasil kerja mahasiswa mengungkapkan bahwa mahasiswa kesulitan dalam memahami simbol definisi, keraguan dalam mengubah simbol definisi ke dalam kalimat biasa, kebingungan menentukan nilai epsilon dan delta, dan kesalahan logika dalam menyelesaikan pembuktian (Oktaviyanthi, Herman \& Dahlan, 2018). Dengan penelusuran tambahan, dapat ditentukan masalah utama mahasiswa yakni kesulitan mengonstruksi frasa definisi formal dan pengetahuan strategik. Selanjutnya kesulitan yang dihadapi mahasiswa tersebut disusun secara rinci yaitu:

1. Tidak memahami konsep proposisi dalam definisi formal Limit.

2. Tidak mengetahui kunci utama dalam mengevaluasi nilai limit menggunakan definisi formal (identifikasi nilai delta).

3. Kesulitan dalam mengubah konsep intuitif ke bentuk aturan formal.

4. Lemahnya argumentasi logis dalam mengonstruksi frasa definisi formal Limit.

Berdasarkan rincian kesulitan mahasiswa tersebut, dirancang instrumen lembar kerja memuat empat soal dengan masing-masing soal mewakili kesulitan mahasiswa. Desain soal tersebut adalah sebagai berikut:

1. Pendekatan mengatasi kesulitan memahami konsep proposisi dalam definisi, desain soal yang dibuat berupa melengkapi diagram alir atau skema dimulai dari penulisan definisi formal secara bahasa latin lalu diubah ke dalam bahasa simbol matematika sampai menemukan pola implikasi 'jika' dan 'maka'.

2. Pendekatan mengatasi kesulitan dalam mengidentifikasi nilai delta, desain soal yang dibuat memadukan penulisan definisi formal dan melengkapi grafik menentukan letak kisaran nilai epsilon dan delta.

3. Pendekatan mengatasi kesulitan mengubah konsep intuitif ke bentuk aturan formal, desain soal yang dibuat berupa melengkapi alur kerja pembuktian nilai limit. 
4. Pendekatan mengatasi kesulitan argumentasi logis dalam mengonstruksi frasa definisi formal limit, desain soal yang dibuat berupa mengisi tabel sistematika pembuktian nilai limit.

\section{Pengembangan}

Lembar kerja terbimbing evaluasi limit menggunakan definisi formal dirancang untuk membantu mahasiswa mengatasi kesulitan yang dihadapi terkait konsep definisi formal limit dan menilai sejauh mana mahasiswa memahami struktur pembuktian nilai limit melalui aturan formal. Dengan demikian, bentuk dan konten soal disusun bersesuaian dengan kebutuhan tersebut yang disampaikan di tahap pertama penelitian yakni analisis dan desain. Pengembangan soal di lembar kerja terbimbing sesuai masalah yang dihadapi mahasiswa adalah sebagai berikut.

1. Soal nomor 1 ditujukan sebagai pengurai kesulitan memahami konsep proposisi dalam definisi.

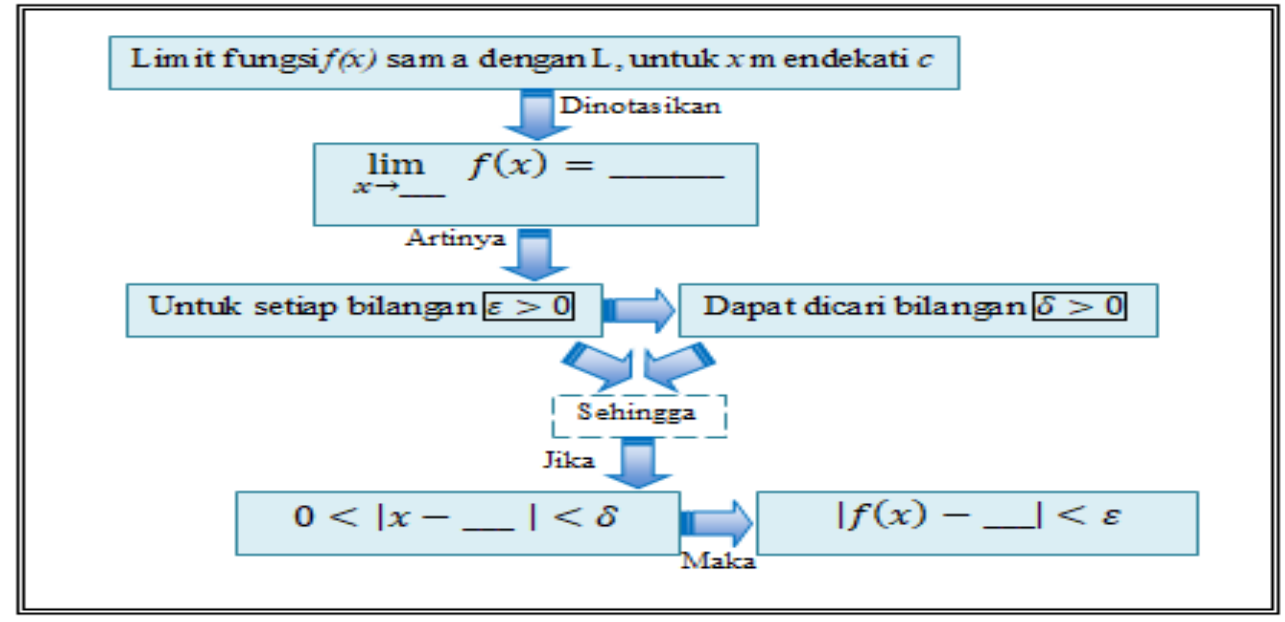

Gambar 2. Desain soal untuk nomor 1

2. Soal nomor 2 ditujukan untuk menyelesaikan kesulitan dalam mengidentifikasi nilai delta.

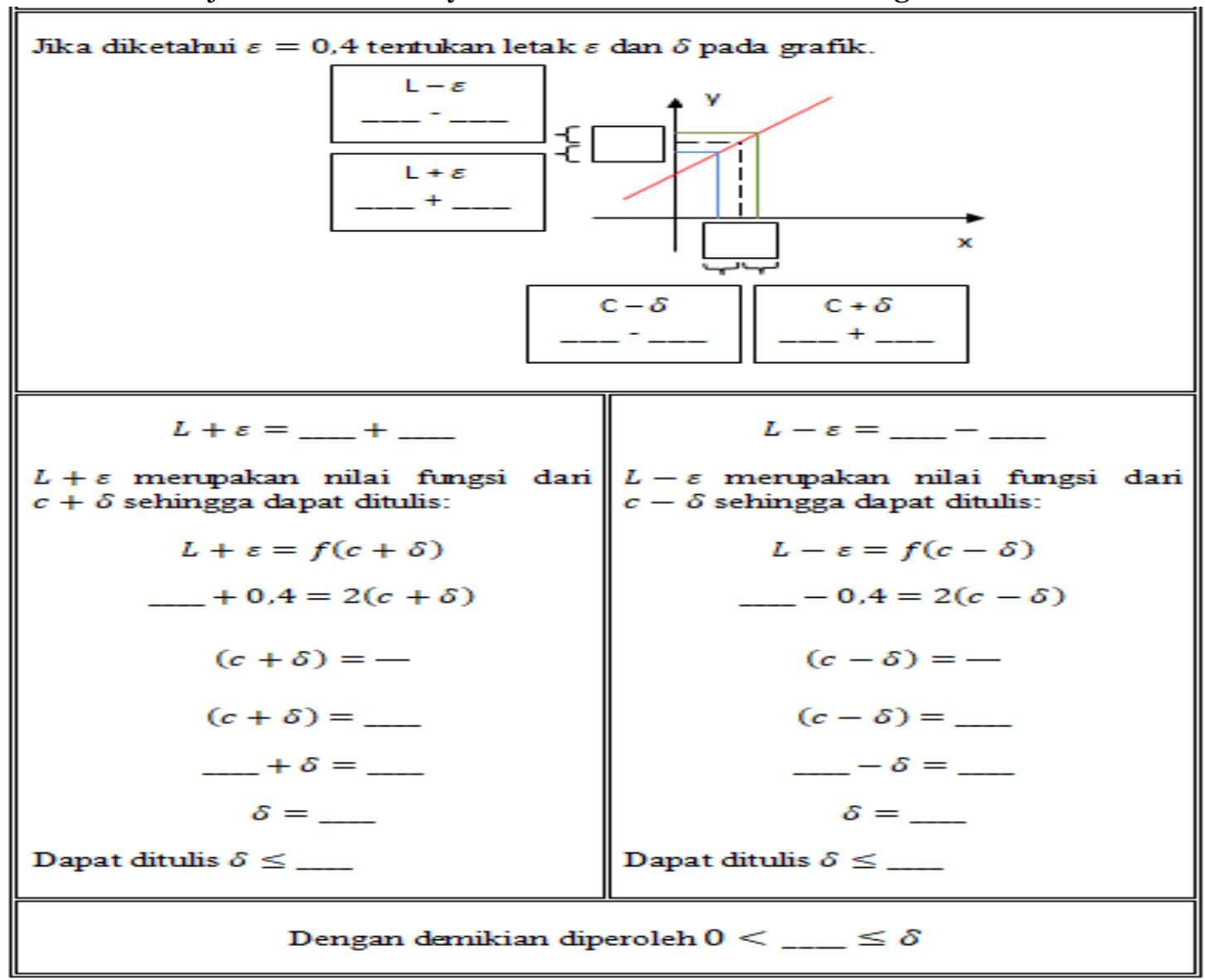

Gambar 3. Desain soal untuk nomor 2 
3. Soal nomor 3 ditujukan sebagai strategi mengubah konsep intuitif ke bentuk aturan formal.

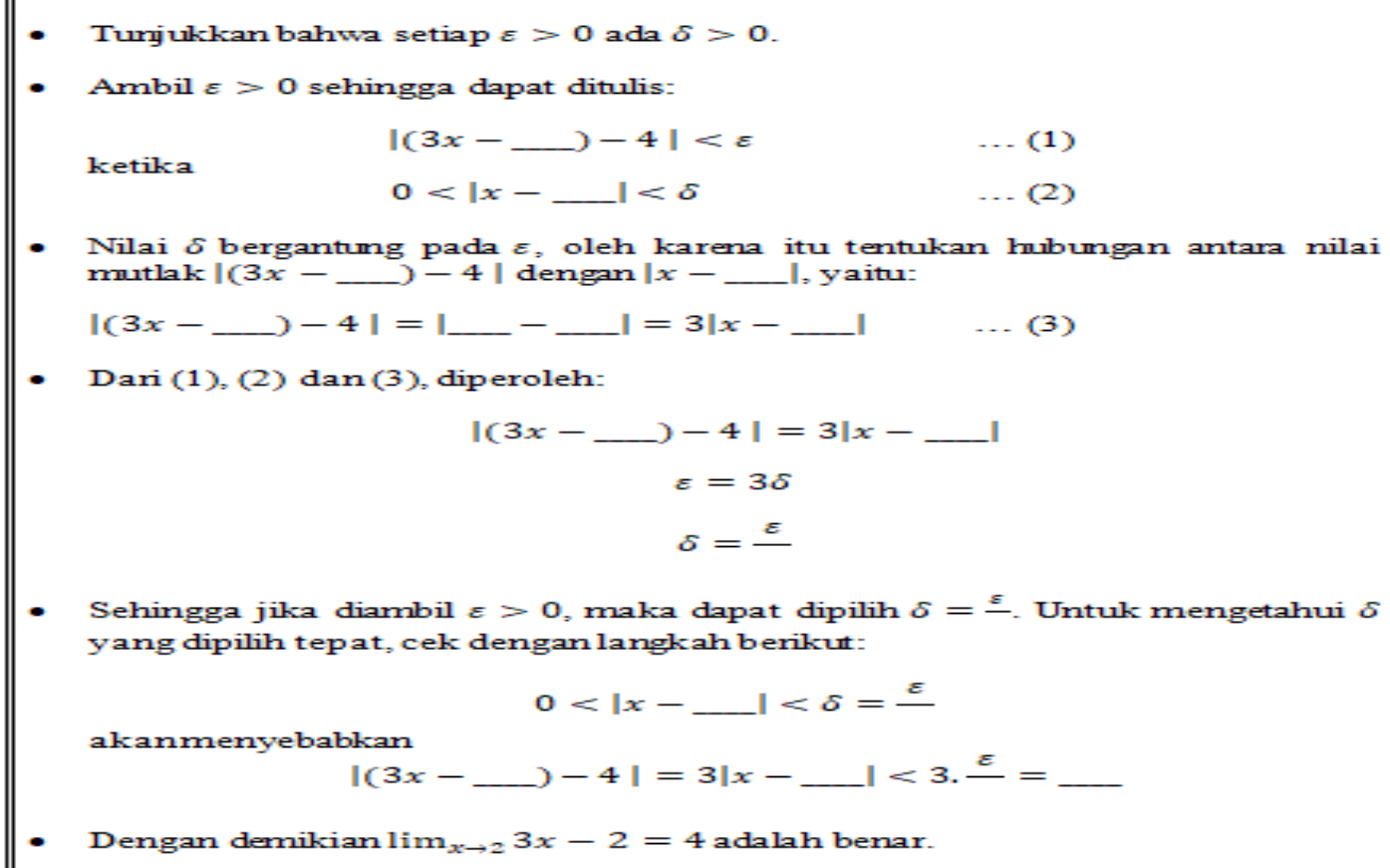

\section{Gambar 4. Desain soal untuk nomor 3}

4. Soal nomor 4 ditujukan untuk merangkai argumentasi logis dalam mengonstruksi frasa definisi formal limit.

\begin{tabular}{|c|c|c|}
\hline a. & $\begin{array}{l}\text { Menentukan nilai } \delta \text { melalui pemyataan } \\
\text { terakhir definisi formal limit. }\end{array}$ & $\|f(x)-L\|<\varepsilon$ \\
\hline b. & $\begin{array}{l}\text { Substitusi nilai } f(x) \text { dan I yang diketahui } \\
\text { dalam soal pada pernyataanpoin a. }\end{array}$ & $\|(\longrightarrow-C-(\longrightarrow<\varepsilon$ \\
\hline c. & $\begin{array}{l}\text { Sederhanakannilai dalamtanda mutlak } \\
\text { padapoin b menjadi seperti bentuk } \\
|x-c|<\delta \text {. }\end{array}$ & $1 \_-1<\varepsilon$ \\
\hline d. & $\begin{array}{l}\text { Menyelesaikan ketaksamaanpa da poin c } \\
\text { sehingga membentuk }|x-c|<\delta \text {. }\end{array}$ & 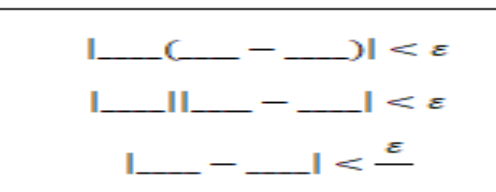 \\
\hline e. & $\begin{array}{l}\text { Menghubungkan berntuk }|x-c|<\delta \\
\text { dengan hasil ketaksamaanyang diperoleh } \\
\text { pa da poin d umtuk mememukan nilai } \delta \text {. }\end{array}$ & $\begin{array}{c}\mathrm{I} \_-1<\frac{\varepsilon}{1}-c \mid<\delta \\
\mid x-\frac{\varepsilon}{\text { Sehingga diperoleh: }} \\
\delta=\frac{\varepsilon}{}\end{array}$ \\
\hline
\end{tabular}

\section{Evaluasi}

\section{Gambar 5. Desain soal untuk nomor 4}

Sebagaimana disampaikan pada bagian metode bahwa tahap evaluasi dilakukan uji keterbacaan dan keseragaman oleh ahli bertujuan untuk memvalidasi isi dan muka lembar kerja terbimbing. Validator ahli mengisi angket dengan 2 skala penilaian terdiri dari penilaian 1 menyatakan setuju dan penilaian o menyatakan tidak setuju. Skor maksimal butir angket adalah 24 . Data angket validasi ahli dihitung menggunakan bantuan perhitungan Statistika melalui uji $Q-$ Cochran. Hasil validasi isi dan muka lembar kerja terbimbing evaluasi nilai limit dengan aturan formal dapat dilihat di Tabel 2. 


\section{Tabel 2. Hasil uji validitas lembar kerja terbimbing evaluasi limit}

\begin{tabular}{ccc}
\hline \multirow{2}{*}{ Instrumen } & \multicolumn{2}{c}{ Nilai (Asymp. Sig.) Q-Cochran } \\
\cline { 2 - 3 } & Validitas Muka & Validitas Isi \\
\hline Lembar Kerja Evaluasi Limit & 0,088 & 0,172 \\
\hline
\end{tabular}

Nilai Asymp.Sig. untuk uji Q-Cochran pada Tabel 2. menunjukkan nilai lebih besar o,05 yang artinya kelima validator ahli menunjukkan kriteria seragam pada pertimbangan validitas isi dan muka instrumen. Implikasi dari keseragaman pertimbangan tersebut yaitu lembar kerja yang disusun dapat digunakan untuk menilai apakah mahasiswa masih merasa kesulitan atau tidak dalam mengevaluasi nilai limit menggunakan definisi formal. Dalam perjalanannya, lembar kerja terbimbing evaluasi limit ini menjalani proses koreksi dan revisi sampai dihasilkan lembar kerja yang tidak hanya mencakup standar penyelesaian masalah penelitian melainkan memenuhi aspek pembahasaan yang efektif. Adapun contoh proses koreksi dan revisi butir soal pada lembar kerja terbimbing disajikan pada Tabel 3 .

Tabel 3. Revisi lembar kerja terbimbing evaluasi limit

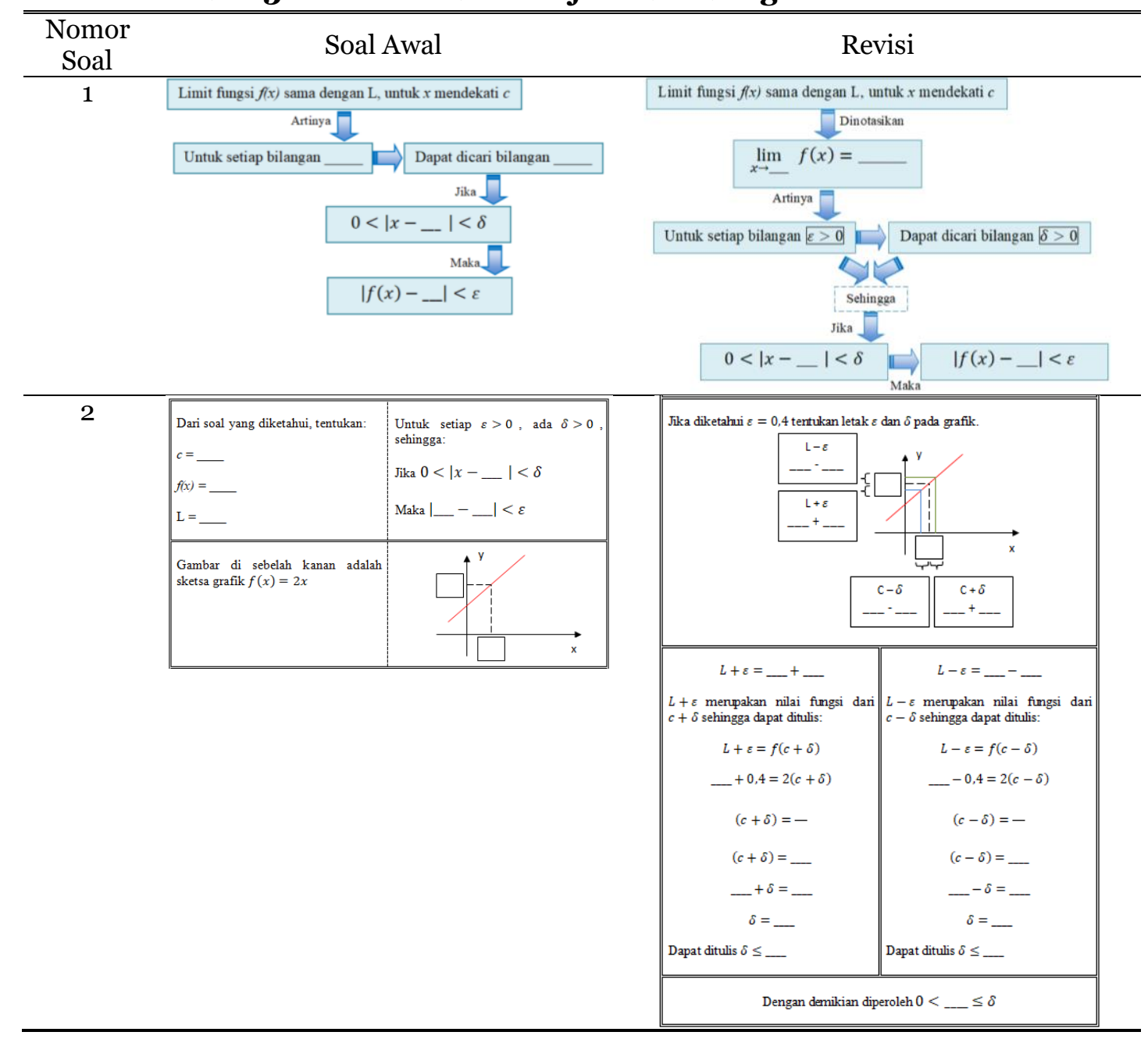

Pada Tabel 3. butir soal nomor 1 diperuntukkan menyelesaikan masalah mahasiswa yang tidak memahami konsep proposisi dalam definisi formal Limit. Indikatornya adalah mahasiswa memahami perubahan bentuk proposisi bahasa latin ke dalam proposisi bahasa simbol matematika. Validator menyarankan setelah dituliskan proposisi bahasa latin pada baris pertama kemudian dituliskan proposisi bahasa simbol matematika di baris kedua dalam bentuk isian yang harus dilengkapi mahasiswa. Validator menambahkan bentuk skematis yang disusun dalam soal dapat lebih optimal jika ditulis bergantian antara proposisi bahasa latin dan proposisi bahasa simbol 
Al- Ishlah: Jurnal Pendidikan, June 2021, 13 (1), Pages 449-461

Rina Oktaviyanthi, Ria Noviana Agus

matematika. Bentuk yang demikian diharapkan dapat memberi stimulus mahasiswa dalam memahami proposisi definisi formal. Selanjutnya butir soal nomor 2 sebagai pendekatan masalah kesulitan dalam mengidentifikasi nilai delta. Indikator soal nomor 2 yaitu mahasiswa dapat mengetahui letak dan bagaimana menentukan nilai delta dengan pendekatan grafik dan menggunakannya dalam mengevaluasi limit. Validator memberi masukan bentuk soal yang dapat menunjukkan letak nilai delta yang mendekati suatu nilai $c$ baik dari kiri maupun kanan.

Lanjutan tahap evaluasi yakni uji coba terbatas yang dilakukan pada 95 responden dengan kualifikasi sedang mengambil mata kuliah Kalkulus. Tujuan uji coba terbatas adalah mengetahui nilai validitas dan reliabilitas prototipe lembar kerja terbimbing yang disusun berdasarkan masalah yang dihadapi mahasiswa. Uji coba diterapkan pada mahasiswa yang sedang mengambil mata kuliah Kalkulus dan sedang mempelajari materi Limit. Mahasiswa menjawab soal dalam lembar kerja terbimbing dalam kurun waktu 60 menit. Lembar kerja terbimbing yang diisi mahasiswa kemudian dinilai dengan skor maksimal 100. Data nilai tersebut dihitung melalui uji Cronbach Alpha menggunakan bantuan SPSS IBM 25. Tabel 4. berikut menunjukkan nilai uji coba lembar kerja terbimbing tersebut.

Tabel 4. Rekapitulasi hasil uji terbatas lembar kerja terbimbing evaluasi limit

\begin{tabular}{ccccc}
\hline \hline $\begin{array}{c}\text { No } \\
\text { Soal }\end{array}$ & $\begin{array}{c}\text { Corrected Item- } \\
\text { Total Correlation } \\
\left(\mathrm{r}_{\text {hitung }}\right)\end{array}$ & Validitas & $\begin{array}{c}\text { Cronbach's Alpha } \\
\text { if Item Deleted } \\
\left(\mathrm{r}_{\text {hitung }}\right)\end{array}$ & Reliabilitas \\
\hline 1 & 0,382 & Valid & 0,663 & Reliabel \\
2 & 0,310 & Valid & 0,638 & Reliabel \\
3 & 0,256 & Valid & 0,612 & Reliabel \\
4 & 0,245 & Valid & 0,577 & Reliabel \\
\hline \hline
\end{tabular}

Kriteria butir soal dalam lembar kerja terbimbing dikatakan valid dan reliabel jika nilai $r_{\text {hitung }}$ $>r_{\text {kritis. }}$ Untuk jumlah responden $(\mathrm{N})$ sebanyak 95 siswa pada $\mathrm{DF}=\mathrm{N}-2$ dengan taraf signifikansi $5 \%$ diperoleh $r_{\text {kritis }}$ yaitu 0,2017. Berdasarkan nilai $r_{\text {kritis }}$ dan $r_{\text {hitung }}$ di kolom Corrected Item-Total Correlation dan kolom Cronbach's Alpha if Item Deleted pada Tabel 2. yang menunjukkan nilai $r_{\text {hitung }}>r_{\text {kritis }}$, maka keempat butir soal di dalam lembar kerja terbimbing evaluasi limit dapat dikatakan valid dan reliabel.

Penelitian ini menghasilkan prototipe lembar kerja terbimbing evaluasi limit sesuai prosedur penelitian pengembangan dan disusun berdasarkan masalah nyata yang dihadapi mahasiswa. Prosedur pengembangan dimulai dari tahap pertama yakni analisis dan desain. Semua kemungkinan masalah dicatat untuk ditelusuri kesesuaiannya dengan rekam jejak hasil belajar mahasiswa selama dua tahun terakhir, media belajar yang digunakan dan pendekatan pembelajaran yang diterapkan dalam kegiatan belajar mengajar. Cohen, Manion \& Morrison (2017) secara implisit mengungkapkan bahwa menginvestigasi seluruh aspek dan komponen kegiatan belajar mengajar yang sudah dilakukan sebelumnya dapat menjadi acuan dalam menemukan potensi kesulitan belajar peserta didik. Aspek kegiatan belajar mengajar dapat berupa aspek kognitif, afektif dan psikomotorik (Japkowicz \& Shah, 2011) dan komponen kegiatan belajar mengajar diantaranya pengajar, peserta didik, metode dan media belajar, pendekatan pembelajaran dan alat evaluasi belajar (Butcher, Davies \& Highton, 2019). Di tahap analisis dan desain ditetapkan 4 butir soal evaluasi limit yang sekaligus menjadi temuan dalam tahapan penelitian ini. Dasar klaim temuan tersebut yakni penyusunan butir soal yang merujuk pada identifikasi masalah yang dirasakan mahasiswa dan dibentuk dalam format terbimbing melalui kerangka-kerangka (scaffolding) dan skematis. Kilic (2018) mengungkapkan soal dengan tipe perancah atau kerangka (scaffolding) dapat membantu mengorganisasikan pemahaman secara terstruktur. Berkaitan dengan itu, Rocha (2019) menegaskan bahwa pemahaman sistematis sangat membantu dalam proses berpikir untuk menyelesaikan masalah pembuktian matematis.

Selanjutnya tahap pengembangan yang menurut Oktaviyanthi \& Agus (2020) merupakan tahap pengaktualan gagasan yang dikembangkan dan didalami dengan terus menerus di tahap analisis dan desain. Target di tahap pengembangan adalah dihasilkannya bentuk visual dari ide 
lembar kerja terbimbing evaluasi limit yang disebut prototipe 1. Prototipe 1 ini kemudian disiapkan untuk menjalani serangkaian uji seperti yang diarahkan Kumar (2018) bahwa rancangan instrumen yang mengukur suatu keterampilan atau keahlian harus diujikan sehingga dapat diketahui kelayakannya. Temuan tahap pengembangan pada penelitian ini adalah lembar kerja terbimbing evaluasi limit dalam bentuk visual dengan desain skematis dan tipe perancah atau kerangka (scaffolding). Temuan tersebut sejalan dengan konsep penelitian Dagoc \& Tan (2018) dan Albano \& Iacono (2019).

Tahap terakhir pada penelitian pengembangan adalah evaluasi yang menjadi bagian penentu keabsahan dan keterjaminan suatu alat ukur penelitian atau instrumen penelitian atau bahan ajar dapat digunakan secara general (Kumar, 2018; Tracy, 2019). Ada dua uji yang dilakukan pada tahap evaluasi yakni uji ahli dan uji terbatas di sampel penelitian. Pada proses uji ahli diketahui bahwa butir soal yang disusun dapat mengakomodasi kesulitan mahasiswa dalam memahami konsep Limit menggunakan definisi formal. Proses tersebut sejalan dengan hasil penelitian Keh \& Sun (2018) dan Dasaprawira, Zulkardi \& Susanti (2019).

Selanjutnya tahap evaluasi yang meliputi kegiatan uji coba ahli dan uji coba skala terbatas. Tujuan kegiatan pengujian instrumen adalah untuk memperoleh validitas dan reliabilitas butir soal yang menyusun lembar kerja terbimbing evaluasi limit. Dari Tabel 1. dan Tabel 2. telah diinformasikan bahwa validator memberikan penilaian seragam terhadap lembar kerja terbimbing yang disusun dan keempat soal di dalam lembar kerja tersebut dinilai valid dan reliabel untuk digunakan. Suatu instrumen penelitian dinyatakan valid dan reliabel artinya instrumen tersebut dapat dijadikan sebagai alat ukur sesuatu dan pengumpul data (Guzey, Harwell \& Moore, 2014; van der Scheer, Bijlsma \& Glas, 2019).

Secara umum keutamaan lembar kerja terbimbing evaluasi limit ini terletak pada indikator dan desain soal yang ditetapkan bersesuaian dengan masalah nyata mahasiswa. Hal tersebut dilakukan sebagai upaya meminimalisir kesulitan mahasiswa dalam definisi formal limit sekaligus menjadi media memahamkan kerangka konsep pembuktian matematika. Sementara yang masih menjadi tantangan adalah meragamkan soal pembuktian sesuai kebutuhan mahasiswa dan yang tidak hanya memokuskan pada konsep Limit serta mentransformasi soal dalam bentuk yang lebih interaktif.

\section{SIMPULAN}

Dengan didasarkan pada hasil dan pembahasan, maka penelitian ini menghasilkan prototipe lembar kerja terbimbing evaluasi limit dengan definisi formal berbentuk soal uraian sebanyak 4 butir. Uji keseragaman 5 validator memberi pertimbangan seragam pada lembar kerja terbimbing tersebut yang ditunjukkan melalui nilai Asymp.Sig. > 0,05 pada uji Q-Cochran. Implikasinya adalah butir soal yang menyusun lembar kerja terbimbing ini dapat digunakan sebagai upaya pendekatan menyelesaikan kesulitan mahasiswa yang berkaitan dengan aturan formal limit. Selanjutnya hasil uji coba terbatas pada 95 mahasiswa yang menjadi responden penelitian diketahui 4 butir soal yang disusun dinyatakan valid dan reliabel. Kelemahan hasil penelitian ini diantaranya yaitu keterbatasan memodifikasi soal yang masih menitikberatkan pada empat masalah mahasiswa dalam konteks mengevaluasi nilai limit. Selain itu, sedikitnya jumlah soal dalam lembar kerja terbimbing memungkinkan soal yang tidak valid semakin tinggi. Kelemahan tersebut menjadi tantangan bagi penulis untuk mengembangkannya lebih lanjut. Adapun yang masih menjadi lanjutan dari penelitian ini adalah implementasi lembar kerja terbimbing dengan melibatkan kelas eksperimen dan kontrol dalam kerangka pembelajaran daring.

\section{DAFTAR PUSTAKA}

Akbar, S. D. (2013). Instrumen perangkat pembelajaran. Bandung: PT Remaja Rosdakarya.

Albano, G., \& Iacono, U. D. (2019). A scaffolding toolkit to foster argumentation and proofs in mathematics: some case studies. International Journal of Educational Technology in 
Higher Education, 16(1), 1-12. https://doi.org/10.1186/s41239-019-0134-5

Alsina, A., Maurandi, A., Ferre, E., \& Coronata, C. (2021). Validating an Instrument to Evaluate the Teaching of Mathematics Through Processes. International Journal of Science and Mathematics Education, 19(3), 559-577. https://doi.org/10.1007/s10763-020-10064-y

Ashraf, A. L. A. M. (2020). Challenges and Possibilities in Teaching and Learning of Calculus: A Case Study of India. Journal for the Education of Gifted Young Scientists, 8(1), 407-433. https://doi.org/10.17478/jegys.660201

Ayalon, M., \& Wilkie, K. J. (2020). Developing assessment literacy through approximations of practice: Exploring secondary mathematics pre-service teachers developing criteria for a rich quadratics task. Teaching and Teacher Education, 89, 103011. https://doi.org/10.1016/j.tate.2019.103011

Bakhy, S., Kalimbetov, B., \& Khabibullayev, Z. (2018). Possibilities of mathematical problems in logical thinking. Development of secondary education pupils. Opción: Revista de Ciencias Humanas y Sociales, (85), 441-457.

Barniol, P., \& Zavala, G. (2016). A tutorial worksheet to help students develop the ability to interpret the dot product as a projection. Eurasia Journal of Mathematics, Science and Technology Education, 12(9), 2387-2398. https://doi.org/10.12973/eurasia.2016.1271a

Butcher, C., Davies, C., \& Highton, M. (2019). Designing learning: from module outline to effective teaching. Routledge.

Cohen, L., Manion, L., \& Morrison, K. (2017). Research methods in education. routledge.

Dagoc, D., \& Tan, D. A. (2018). Effects of metacognitive scaffolding on the mathematics performance of grade 6 pupils in a cooperative learning environment. International Journal of English and Education, 7(4), 378-391.

Dasaprawira, M. N., Zulkardi, \& Susanti, E. (2019). Developing Mathematics Questions of PISA Type Using Bangka Context. Journal on Mathematics Education, 10(2), 303-314. https://doi.org/10.22342/jme.10.2.5366.303-314

Dibbs, R. (2019). Forged in failure: engagement patterns for successful students repeating calculus. Educational Studies in Mathematics,101(1), 35-50. https://doi.org/10.1007/s10649-019-9877-o

Flórez, R., \& Mukherjee, A. (2020). Classroom Experiences in Introducing Students to Conjectures, Exploration and Visual Proofs Using Experiments on the Möbius Strip. PRIMUS, 3O(1), 5066. https://doi.org/10.1080/10511970.2018.1506530

Guzey, S. S., Harwell, M., \& Moore, T. (2014). Development of an instrument to assess attitudes toward science, technology, engineering, and mathematics (STEM). School Science and Mathematics, 114(6), 271-279. https://doi.org/10.1111/ssm.12077

Hagman, J. E., Johnson, E., \& Fosdick, B. K. (2017). Factors contributing to students and instructors experiencing a lack of time in college calculus. International journal of STEM education, 4(1), 1-15. https://doi.org/10.1186/s40594-017-0070-7

Hanna, G. (2020). Mathematical proof, argumentation, and reasoning. Encyclopedia of mathematics education, 561-566. https://doi.org/10.1007/s10649-021-10046-Z

Kahl, W. (2020). Calculational relation-algebraic proofs in the teaching tool CalcCheck. Journal of Logical and Algebraic Methods in Programming, 117, 100581. https://doi.org/10.1016/j.jlamp.2020.100581

Katrancı, M. (2015). Book reading motivation scale: Reliability and validity study. Educational Research and Reviews, 1O(3), 300-307. https://doi.org/10.5897/ERR2014.1998

Keh, H. T., \& Sun, J. (2018). The differential effects of online peer review and expert review on service evaluations: the roles of confidence and information convergence. Journal of Service Research, 21(4), 474-489. https://doi.org/10.1177/1094670518779456

Kilic, H. (2018). Pre-service mathematics teachers' noticing skills and scaffolding practices. International Journal of Science and Mathematics Education, 16(2), 377-400. https://doi.org/10.1007/s10763-020-10101-w

Kumar, R. (2018). Research methodology: A step-by-step guide for beginners. Sage.

Krosnick, J. A. (2018). Questionnaire design. In The Palgrave handbook of survey research (pp. 439-455). Palgrave Macmillan, Cham.

Ingram, N., Holmes, M., Linsell, C., Livy, S., McCormick, M., \& Sullivan, P. (2019). Exploring an innovative approach to teaching mathematics through the use of challenging tasks: a New Zealand perspective.Mathematics Education Research Journal, 1-26. https://doi.org/10.1007/s13394-019-00266-1 
Japkowicz, N., \& Shah, M. (2011). Evaluating learning algorithms: a classification perspective. Cambridge University Press.

Leikin, R., \& Elgrably, H. (2020). Problem posing through investigations for the development and evaluation of proof-related skills and creativity skills of prospective high school mathematics teachers. International Journal of Educational Research, 102, 101424. https://doi.org/10.1016/j.ijer.2019.04.002

Lithner, J. (2017). Principles for designing mathematical tasks that enhance imitative and creative reasoning. $Z d m$, 49(6), 937-949. https://doi.org/10.1007/s11858-017-0867-3

Luthfiana, A., Ambarita, A., \& Suwarjo, S. (2018). Developing worksheet based on multiple intelligences to optimize the creative thinking students. JIPM (Jurnal Ilmiah Pendidikan Matematika), 7(1), 1-12. http://doi.org/10.25273/jipm.v7i1.2430

Mohajan, H. K. (2017). Two criteria for good measurements in research: Validity and reliability. Annals of Spiru Haret University. Economic Series, 17(4), 59-82. https://10.26458/1746

Nasrullah, A., Marlina, M., \& Dwiyanti, W. (2018). Development of Student Worksheet-Based College E-Learning Through Edmodo to Maximize the Results of Learning and Motivation in Economic Mathematics Learning. International Journal of Emerging Technologies in Learning, 13(12). https://doi.org/10.3991/ijet.v13i12.8636

Oktaviyanthi, R., Herman, T., \& Dahlan, J. A. (2018). How Does Pre-Service Mathematics Teacher Prove the Limit of a Function by Formal Definition?. Journal on Mathematics Education, 9(2), 195-212. https://doi.org/10.22342/jme.9.2.5684.195-212

Oktaviyanthi, R., \& Dahlan, J. A. (2018, April). Developing guided worksheet for cognitive apprenticeship approach in teaching formal definition of the limit of a function. In IOP Conference Series: Materials Science and Engineering (Vol. 335, No. 1, p. 012120). IOP Publishing. https://doi.org/10.1088/1757-899X/335/1/012120

Oktaviyanthi, R., \& Agus, R. N. (2020). Instrumen Evaluasi Kemampuan Penalaran Adaptif Matematis Mahasiswa. AKSIOMA: Jurnal Program Studi Pendidikan Matematika, 9(4). http://dx.doi.org/10.24127/ajpm.v9i4.3150

Richard, P. R., Venant, F., \& Gagnon, M. (2019). Issues and challenges in instrumental proof. In Proof Technology in Mathematics Research and Teaching (pp. 139-172). Springer, Cham. https://doi.org/10.1007/978-3-030-28483-1_7

Richey, R. C., Klein, J. D., \& Tracey, M. W. (2010). The instructional design knowledge base: Theory, research, and practice. Routledge.

Rocha, H. (2019). Mathematical proof: from mathematics to school mathematics. Philosophical Transactions of the Royal Society A, 377(2140), 20180045. https://doi.org/10.1098/rsta.2018.0045

Schoenfield, M. (2018). An accuracy based approach to higher order evidence. Philosophy and Phenomenological Research, 96(3), 690-715. https://doi.org/10.1111/phpr.12329

Spivak, M. (2018). Calculus on manifolds: a modern approach to classical theorems of advanced calculus. CRC press.

Tracy, S. J. (2019). Qualitative research methods: Collecting evidence, crafting analysis, communicating impact. John Wiley \& Sons.

van der Scheer, E. A., Bijlsma, H. J., \& Glas, C. A. (2019). Validity and reliability of student perceptions of teaching quality in primary education. School effectiveness and school improvement, 3o(1), 30-50. https://doi.org/10.1080/09243453.2018.1539015 